Archives of Agriculture and Environmental Science

\title{
Price behavior, marketing and consumption pattern of tomato in selected region of western Nepal
}

\section{Saurav Maharatha* (D) , Bhishma Raj Dahal, Nobel Acharya and Shivahari Devkota}

Agriculture and Forestry University, Rampur, Chitwan, NEPAL

*Corresponding author's E-mail: saurav.marahatta@gmail.com

\section{ARTICLE HISTORY}

Received: 31 October 2019

Revised received: 27 November 2019

Accepted: 04 December 2019

\section{Keywords}

Consumption pattern

Farm gate price

Marketing channel

Price behaviour

\begin{abstract}
Tomato is an important marketable vegetable commodity of Nepal; but, due to involvement of middlemen farmers are receiving low price margin, meanwhile, consumer are compelled to pay higher. Keeping these points in view, an attempt has been made to study price behavior, marketing and consumption pattern of tomato in Western Nepal. Pre-tested semi-structured questionnaire was administered among randomly selected 90 tomato producers and 10 retailers during march-April 2018. Reports from ministry of agricultural development and journal articles were sources of secondary data. The empirical evidences revealed that, farm gate price, retailers' price, and price spread was higher for off-seasonal tomato production while producers share was higher for seasonal production; in addition, price of tomato, for both seasons, was increasing. Market analysis depicted, producer-wholesaler-retailer-consumer was the major market channel involved. Low market price, dominancy of wholesaler in price determination, storage problems (mainly in off-season), and malpractices during post-harvest handling were the major problems of marketing. Overall, our study point out that, addressing the mentioned problems, accessing new markets, checking unscrupulous middlemen, and value addition are crucial for sustainable market development.
\end{abstract}

(C)2019 Agriculture and Environmental Science Academy

Citation of this article: Maharatha, S., Dahal, B.R., Acharya, N. and Devkota, S. (2019). Price behavior, marketing and consumption pattern of tomato in selected region of western Nepal. Archives of Agriculture and Environmental Science, 4(4): 472-477, https://dx.doi.org/10.26832/24566632.2019.0404014

\section{INTRODUCTION}

Tomato (Solanum lycopersicum) belongs to night shade family; with edible soft red fruit, often known as berry, served as salads and part of the main dish-vegetable. Consumer's increasing desire for high quality and nutritional foods has created a need for longer market demand of vegetables for both domestic as well as foreign markets; similar is the scenario for tomato in western Nepal. Market is the area or place where movement of goods take place resulting in exchange of the title of goods (Backman and Davidson, 1962); similarly, Kotler and Armstrong, (1991) stated marketing as the social and managerial process of creating, attaining and exchanging products of value to others, such that the individuals involved get what they want or need. The marketing of vegetable crop is a complex activity and special management or intervention is needed (Sharma, 2009); it begins at farm as farmer expects to meet demands of the market (Awasthi, 2007). Marketing system are the overall activities through which commodity undergoes, before reaching to the next level in the marketing channel (Acharya and Agarwal, 1999); it involves wide range of activities for delivering goods from one hand to another. The vegetable marketing system of Nepal is still in the developing stage which is characterized by unequal distribution of opportunities between producers and traders (Adhikari, 2002). Efficient marketing system minimizes the costs and provides benefit to all sections of the society (Acharya and Agarwal, 1999); but, due to unfair trading, producers are compelled to receive unfair price while consumer are forced to pay higher. The high markeing cost of vegetables is partly due to higher post harvest loss (Poudel, 2013); in addition, scarcity of produce duing off-season is the another cause of price flucation. This is especially true for tomatoes, 
which ranks number one among vegetables contributing vitamins and minerals (Chapagain, 2010) to Nepalese. Changing consumption pattern and escalating market demand every year has resulted in the cultivation of tomato in new location (PACT, 2014), but still larger profit was shared by middlemen. When price of tomato fetches NRs $5 / \mathrm{kg}$ during major harvesting time, it goes as high as NRs 75/kg during off-season. The buyers fix price with respect to the market demand and export/import opportunities (Bhandari et al., 2016). Thus, a dynamic and vibrant marketing system without least involvement of unscrupulous middlemen, but with decent supply chain infrastructure has been felt necessary to keep balance with ballooning market demand and changing agricultural production. To achieve such a magnificent goal, agriculture produce must be regulated to protect farmers and consumers from exploitation by enacting policies; for this, in depth study of price behavior, marketing, and consumption pattern is felt necessary. Keeping these points in view, a study was undertaken to determine price behavior, marketing and pattern of tomato consumption in selected part of Western Nepal.

\section{MATERIALS AND METHODS}

The study was conducted in Salyan district, a typical mid-hill of Karnali province. Subtropical being dominant, climate here ranges from tropical to sub-temperate. Average annual maximum and minimum temperature were recorded as $31^{\circ} \mathrm{C}$ and $3^{\circ} \mathrm{C}$ respectively. The area was purposefully selected as there were identifiable numbers of farmers involved in production and marketing tomato since last five years. Pre-tested semistructure questionnaire was administered among randomly selected 90 producers and 10 traders involved in tomato enterprise since last five years. Primary data was obtained by using simple random sampling without replacement technique; however, Ministry of agricultural development, journal, kalamiti vegetable market were the sources of secondary data. Face to face interview was scheduled to obtain data during March-April, 2018. One Focus group discussion and two Key Informant Interviews were conducted to validate the data obtained from survey. The data collected from the study were coded, tabulated, and analyzed by using Microsoft excel and SPSS. Price behavior and marketing of tomato in the study area was carried out by using descriptive statistics (like mean, standard deviation), Inferential statistics (like chi-square test, t-test) and Analytical statistics (trend analysis), with the help of different statistical software like Microsoft Excel, SPSS and STATA.

Analysis of price spread and producer's share

Price spread is the difference between the retailers' price and farm gate price, which was calculated by the formula:

Price Spread $=$ Retailers' price - Farm gate price

Similarly, producer's share is the price received by the farmer expressed as percentage of the retail price (Ahmad et al., 2017).
An increase in the producer's share is the indicator of increase in the efficiency of marketing system in the favor of producers/ farmers and vice-versa; a decrease in the producers share indicates that the middlemen are controlling market. Producers share was calculated by the following formula:

\section{Producer's Share $(P S)=\{$ Farm gate price/Retailers' price $\} \times 100$}

\section{Trend analysis}

Trend analysis is a technique used for extracting and underlying pattern of behavior in time series. Trend analysis is based on the idea that what has happened in the past, gives traders an idea of what will happen in the future. Trend analysis involved the collection of information of the last three years data on farm gate price and retailers' price, and plotting the information on a horizontal line. The intent of this analysis is to spot actionable patterns in the price trend as well as price spread trend. The linear trend model is:

$$
Y_{t}=\beta 0+\beta 1 t+\text { et }
$$

Where,

$$
\begin{aligned}
& \beta 0=\text { Constant } \\
& \beta 1=\text { Average change from one period to the next } \\
& t=\text { value of the time unit } \\
& \text { et }=\text { the error term }
\end{aligned}
$$

Indexing of marketing problem

Scaling technique provides the intensity of respondents towards the propositions. Farmers' and traders perception towards the marketing problems was presented in the five point scale comprising most severe, severe, moderate, mild and most mild. The scale values of $1,0.8,0.6,0.4$ and 0.2 was used to most severe, severe, moderate, mild and most mild problem, respectively. It was computed using the following formula: Mathematically,

Where,

$$
\mathrm{I}_{\mathrm{imp}}=\sum=(\text { Sifi } / N)
$$

$$
\begin{aligned}
& \mathrm{I}_{\mathrm{imp}}=\text { Index of importance } \\
& \mathrm{Si}=\text { Scale value } \\
& \mathrm{f}=\text { Frequency of respondents } \\
& \mathrm{N}=\text { Total number of respondents }
\end{aligned}
$$

\section{RESULTS AND DISCUSSION}

\section{Demand, supply and consumption trend of tomato}

The national demand or daily consumption of tomato has increased from $881.5 \mathrm{mt}$ in 2012 to $932.6 \mathrm{mt}$ in 2016, indicated tomato is highly demanded vegetable crop in Nepal (Bhandari et al., 2016). But, Far western region required $73.5 \mathrm{mt}$ in 2012, the lowest compared to other regions, while it has reached to 74.7 $\mathrm{mt}$ per day in 2016; the region has lowest consumption of tomato (9.87 Kg/year /person) in comparison to other four development region-around $12 \mathrm{Kg}$. Consumers from Mountainous belt consumed low amount of tomato (51.2mt per day), in 2015 , 
Table 1. Percentage of tomato consumption by source.

\begin{tabular}{lll}
\hline Region & Home production (\%) & Purchase (\%) \\
\hline Nepal & 21.80 & 78.20 \\
Eastern & 270 & 73.00 \\
Central & 9.20 & 90.90 \\
Western & 20.60 & 79.40 \\
Mid-western & 51.00 & 49.00 \\
Far-western & 51.70 & 48.30 \\
\hline
\end{tabular}

Source: (Ghimire et al., 2017).

compared to other geographical regions. In 2016, the demand of tomato has reached to $51.6 \mathrm{mt}$ in Mountainous region while it has reached to $485.3 \mathrm{mt}$ per day in terai (Ghimire et al., 2017). More than half (about 57 percent) of tomato production was consumed by producers themselves and remaining 43 percent enters into marketing chain (CBS, 2010). In terms of trade, the lowest volume (low demand) was recorded in September/ October while the highest volume (high demand) of tomato trade was found in May/June; this can be ascribed by the fact, Sept-Oct is the off season and May-June is the main season. In addition, tomato production is higher during main season as tomato cultivation can be done with least investment in an open field.

The results showed that consumption of tomato through purchase was highest in central development region (90.9\%) followed by western, eastern, mid-western and far-western region. (Table 1). A plausible explanation to this statement is ascribed by the fact that, people of central development region have high purchasing power (Vandernoot and Hove, 2014). In addition, rapid urban growth of Kathmandu valley, a part of central Nepal, has increased consumption of tomato (Ishtiaque et al., 2017). Consumer from mountain belts purchased lesser than other geographical region (Ghimire et al., 2017), the reason besides higher consumption of tomato through purchasing in terai might be due to the fact that, about $50 \%$ of the population lives in Terai (CBS, 2011).

\section{Monthly price variation}

If the sector is fragmented into a large number of small-scale farmers and producers, it was found that, prices was largely controlled by wholesale traders (ILO, 2014). The price of tomato ranged from Rs 80 in Oct-Nov to Rs. 50 in March-April in Salyan (DADO, 2016); similar variation of price was found all across the country (Prasain, 2019), presented in Figure 1.

\section{Farm gate price}

Farm gate price is the price attained by producers or farmers in the marketing chain. Comparison of off-season and seasonal tomato production at the farmers' level showed that, the difference between farm gate prices was statistically highly significant at $1 \%$ level of probability. The price of off-season and seasonal tomato in the year 2072 was NRs. 35.75 and NRs. 24.27, in the year 2073 was NRs. 39.53 and NRs. 27.43, and in the year
2074 were NRs. 43.75 and NRs. 30.00, respectively (Table 2). Increasing trend of farm gate price is in accordance with (Bhandari et al., 2015 and Prasain, 2019).

\section{Price spread and producers' share of tomato}

The marketing margin and producers' share of tomato in the last 3 years from 2072 to 2074 of the study area at different marketing chain revealed that, the farm gate price for the off-season produce in the year 2072, 2073 and 2074 was NRs. 35.75, NRs. 39.53 and NRs. 43.75, respectively whereas for the seasonal tomato, farm gate price was NRs. 24.27, NRs. 27.43 and NRs. 30, respectively. The farmers generally sold their produce either directly to wholesaler or retailer. The retailers' price for off-season tomato in the year 2072, 2073 and 2074 are NRs. 56.5, NRs. 63 and NRs. 67.5, respectively whereas for seasonal tomato, retailers' price was NRs. 36.5, NRs. 41 and NRs. 46.5, respectively. The producers' share in the off-season and seasonal tomato in the year 2072, 2073 and 2074 are 63.3\%, 62.8\%, $64.8 \%$ and $66.5 \%, 66.9 \%$ and $64.5 \%$, respectively. The producers were more or less constantly getting the equal share of returns in both the seasons. According to the study, it was found that the price spread for off-season and seasonal tomato in 2072, 2073 and 2074 are NRs. 20.75, NRs. 23.47, NRs. 23.75 and NRs. 12.23, NRs. 13.57, NRs. 16.5, respectively (Table 3). The data were based on the household interview on 60 samples obtained from off-season growers, 30 from the seasonal growers and 10 were collected with the retailers' from diverse locations within the vegetable block area.

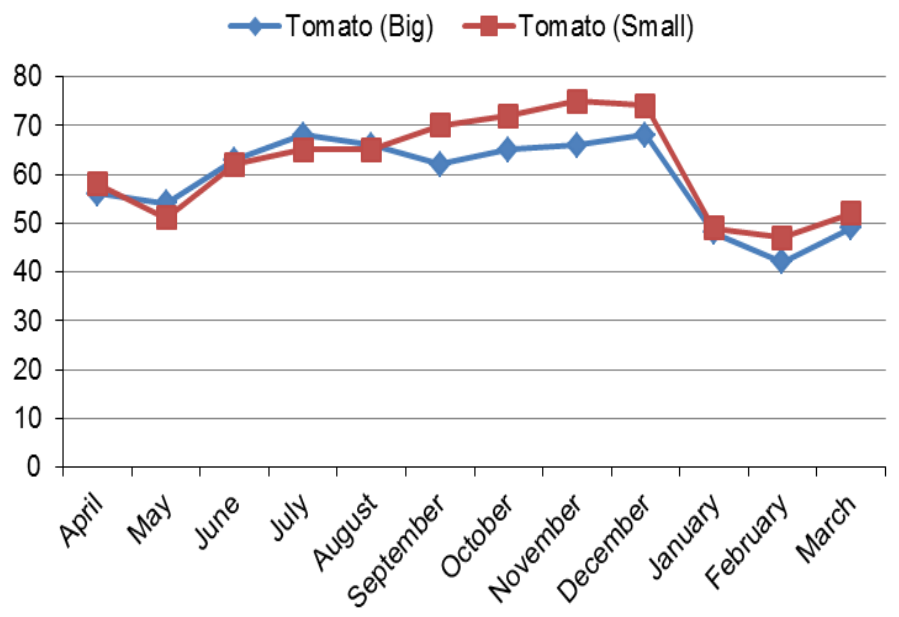

Figure 1. Monthly national retail price of tomato (MoAD, 2015/16). 
Table 2. Farm gate price trend analysis.

\begin{tabular}{|c|c|c|c|c|c|c|}
\hline \multirow[b]{2}{*}{ Year } & \multicolumn{2}{|c|}{ Price in different years (NRs.) } & \multirow[b]{2}{*}{ Overall } & \multirow{2}{*}{$\begin{array}{c}\text { Mean } \\
\text { Difference }\end{array}$} & \multirow[b]{2}{*}{$\mathrm{t}$ - value } & \multirow[b]{2}{*}{ p-value } \\
\hline & $\begin{array}{l}\text { Off-Season Growers } \\
(n=60)\end{array}$ & $\begin{array}{l}\text { Seasonal Growers } \\
(n=30)\end{array}$ & & & & \\
\hline 2072 & $35.75(6.63)$ & $24.27(5.44)$ & $\begin{array}{l}31.92 \\
(8.27)\end{array}$ & $11.48^{* * *}$ & 8.203 & 0.001 \\
\hline 2073 & $39.53(5.59)$ & $27.43(6.62)$ & $\begin{array}{l}35.50 \\
(8.24)\end{array}$ & $12.10^{* * *}$ & 9.099 & 0.001 \\
\hline 2074 & $43.75(5.87)$ & $30.00(6.70)$ & $\begin{array}{l}39.17 \\
(8.94)\end{array}$ & $13.75^{* * *}$ & 9.994 & 0.001 \\
\hline
\end{tabular}

Figures in the parenthesis indicate standard deviation. ${ }^{* * *}$ indicate level of significance at $1 \%$.

Table 3. Producers' share and price spread in seasonal and off-season tomato.

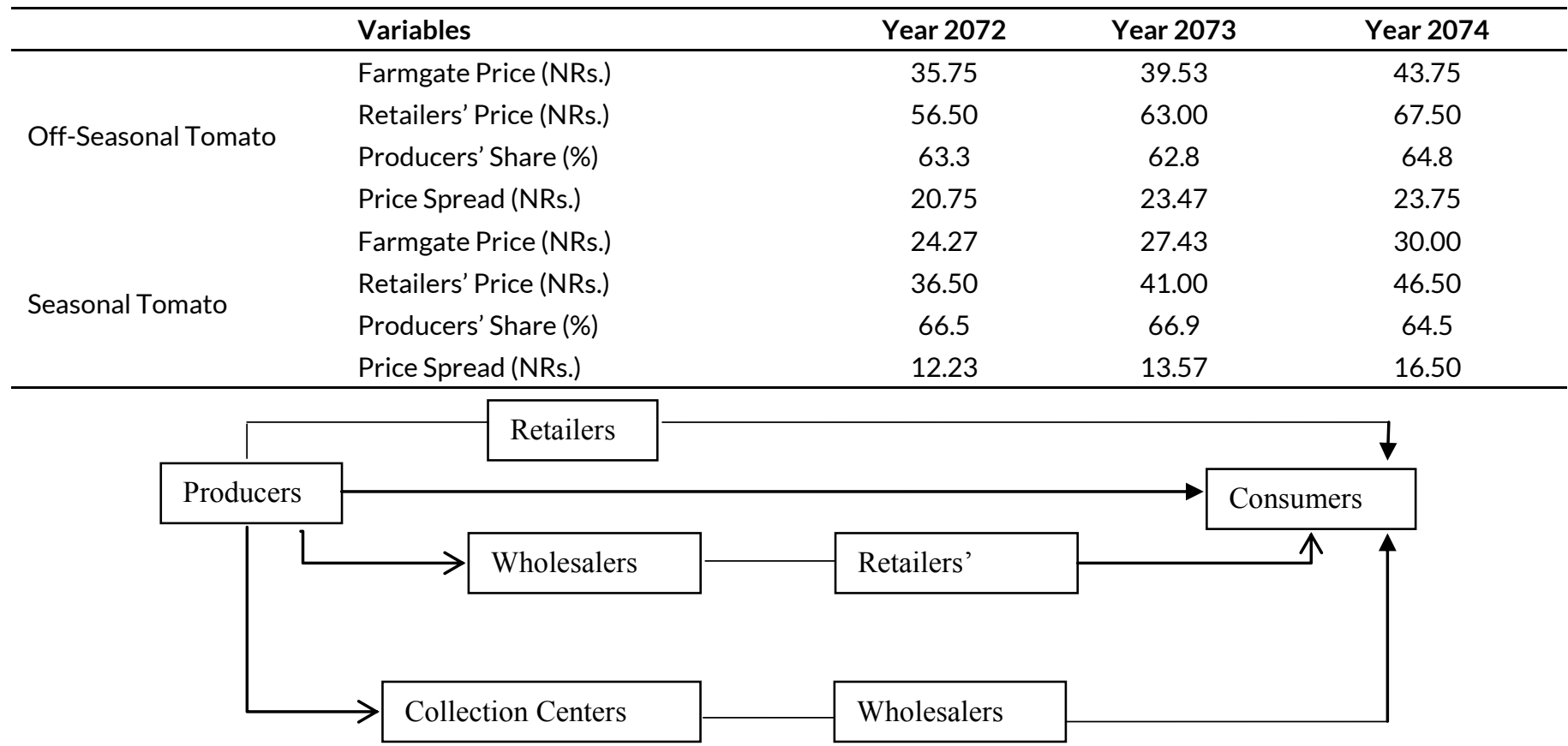

Figure 2. Marketing channels of tomato growers in the study area.

Table 4. Market channel and its actors.

\begin{tabular}{|c|c|c|c|c|c|}
\hline \multirow[b]{2}{*}{ Variable } & \multicolumn{2}{|c|}{ Farmers category } & \multirow[b]{2}{*}{ Overall } & \multirow[b]{2}{*}{$\begin{array}{l}\text { Chi } \\
\text { square }\end{array}$} & \multirow[b]{2}{*}{ Pvalue } \\
\hline & $\begin{array}{c}\text { Off-Season } \\
\text { Growers }(n=60)\end{array}$ & $\begin{array}{c}\text { Seasonal } \\
\text { Growers }(n=30)\end{array}$ & & & \\
\hline $\begin{array}{l}\text { Producer-Wholesaler-Retailer- } \\
\text { Consumer }\end{array}$ & $38(63.3)$ & $19(63.3)$ & $57(63.3)$ & 2.200 & 0.333 \\
\hline Producer-Retailer-Consumer & $14(23.3)$ & $4(13.3)$ & $18(20.0)$ & & \\
\hline Both & $8(13.3)$ & $7(23.3)$ & $15(16.7)$ & & \\
\hline
\end{tabular}

Figures in the parenthesis indicate percentage.

Marketing channel and involved actors

The marketing channel of tomato, starting from producer to the consumer is presented in the Figure 2. Shreenagar, the biggest city of study area is near to the producers thus farmers had access to district wholesale and retail markets. Major retail spots were Dhorchaur, Barala, Shreenagar, Khalanga and Lanti where farmers sold their produce to vegetable retail shops. Sometimes, farmers sold their produce to the consumers directly from the farm, although in small bulk.

The survey in the study site showed two major types of marketing channel; but, when small bulks and frequency were considered, four types of marketing channel were identified. The farm- ers of the study site have majorly used Producer-WholesalerRetailer-Consumer channel; 38 (63.3\%) of the off-seasonal and 19 (63.3\%) of seasonal farmers were using this channel for marketing. Similarly, Producer-Retailer-Consumer channel was used by 14 (23.3\%) of the off-seasonal and 4 (13.3\%) of seasonal tomato growers of the study site; the remaining farmers rather used both the channels equally (Table 4). Similar result on marketing channel of off-season vegetables was obtained by (MoAD, 2011 and Bhandari et al., 2016). The major price determining actors were wholesalers as responded by $48(80.0 \%)$ and 24 (80.0\%) for the off-season and seasonal tomato growers respectively. 
Table 5. Marketing problems of tomato producers in the study area.

\begin{tabular}{|c|c|c|c|}
\hline Problems in Marketing & Production type & Index & Rank \\
\hline \multirow{2}{*}{ Low price } & Off-Season & 0.744 & 1 \\
\hline & Season & 0.854 & 1 \\
\hline \multirow{2}{*}{ Lack of market information } & Off-Season & 0.614 & IV \\
\hline & Season & 0.654 & III \\
\hline \multirow{2}{*}{ Wholesaler dominancy } & Off-Season & 0.634 & III \\
\hline & Season & 0.754 & II \\
\hline \multirow{2}{*}{ Lack of storage } & Off-Season & 0.730 & II \\
\hline & Season & 0.480 & IV \\
\hline \multirow{2}{*}{ Malpractices in market } & Off-Season & 0.280 & $\mathrm{~V}$ \\
\hline & Season & 0.260 & $\mathrm{~V}$ \\
\hline
\end{tabular}

\section{Problems of marketing}

The details of marketing problems faced by the tomato growers are presented in the Table 5. The result showed that low market price received by farmers was the major marketing problem realized by both the sampled off-seasonal and seasonal tomato producers, similar result was obtained by Ghimire et al.( 2017). The second major problem was lack of storage in case of offseason growers and wholesalers' dominancy in case of seasonal growers. The storage problem observed in off-season is ascribed by the fact that climate in the rainy season do not favor the longer shelf life of tomato but in the winter season, temperature itself favors the longer post-harvest life; the findings is in accordance with Timsina and Shivakoti (2018). Wholesalers' dominancy was seen as the next major problem in off-season but lack of market information was the third major problem in the seasonal tomato production. The other problem faced by the farmers was the malpractices in the market which was low in the study site. This might be due to the fact, Nepalese farmers have paucity of knowledge in post-harvest handling of vegetables.

\section{Conclusion}

The results from the study revealed that, farm gate price, retailers' price, and price spread was higher for off-seasonal tomato production for all the three year and they were following increasing trend but producers share was higher for seasonal production; in addition, trend analysis revealed that retail price of tomato was increasing. Further, producer-wholesaler-retailerconsumer was the major market channel involved; wholesalers are the major factors that determine the price of tomato. Low market price, dominancy of wholesaler in price determination, storage problems (mainly in off-season), and malpractices during post-harvest handling were the major problems of marketing. The storage problem of tomato in off-season is ascribed by the fact, off-season tomato production was done during monsoon; higher humidity and temperature during this period shortens the storage life of perishable commodity like tomato. Overall, from our study it would be better to suggest policy makers and concerned bodies, to address the mentioned problems, access new markets, check unscrupulous middlemen, and value addition are crucial for sustainable market development. In addition, developing good cold-storage facility could solve the problem of price fluctuation.
Open Access: This is an open access article distributed under the terms of the Creative Commons Attribution 4.0 License, which permits unrestricted use, distribution, and reproduction in any medium, provided the original author(s) if the sources are credited.

\section{REFERENCES}

Acharya, S.S. and Agarwal, N. L. (1999). Agricultural Marketing in India. New Delhi, India: Oxford and IBH Publishing Co. Pvt. Ltd.

Adhikari, A. (2002). Oxford and IBH Publishing Co. Pvt. Ltd. Master Dissertation, Tribhuwan University, Nepal.

Ahmad, N., Mishra, R.R., Sinha, D.K. and Singh, K.M. (2017). Price spread and vegetables marketing in the Hinterlands of Pusa and Tajpur blocks of Samastipur district of Bihar( India). International Journal of Advances in Agricultural Sciences and Technology , 4 (10).

Awasthi, B.D. (2007). Relevance of market information system to environment protection. Journal of Agriculture and Environment , 46-54.

Backman, T. and Davidson, R. (1962). Marketing Principle. New York: The Ronal Presses Co., NY.

Bhandari, N.B., Bhattarai, D. and Aryal, M. (2015). Cost, production and price spread of cereals in Nepal: A time series analysis. Hariharbhawan, lalitpur: Agribusiness Promotion and Marketing Development Directorate, Ministry of Agriculture Development, Government of Nepal.

Bhandari, N.B., Bhattarai, D. and Aryal, M. (2016). Demand and Supply Situation of Tomato in Nepal. Hariharbhawan, Nepal: Market Reasearch and Statistics Management Program, Agribusiness Promotion and Marketing Development Directorate, Ministry of Agriculture Development, Government of Nepal.

CBS. (2010) Central Bueau of Statistics, Government of Nepal

CBS. (2011). Population distribution and composition, Nepal, 1971-2011. Kathmandu, Nepal: Central Bureau of Statistics, Government of Nepal.

Chapagain, T.P. (2010). Up-scaling of polyhouse tomato production technology in mid and high hills of eastern Nepal. ninth national outreach research workshop (pp. 116-120). Kathmandu: Outreach Research Division, Nepal Agriculture Research Council, Kathmandu.

DADO. (2016). Agriculture Yearbook. Salyan: DADO

Ghimire, N.P., Kandel, M., Aryal, M. and Bhattarai, D. (2017). Assestment of tomato consumption and demand in Nepal. The Journal of Agriculture and Environment, 18, https://doi.org/10.3126/aej.v18i0.19893

ILO. (2014). Market Study and Marketing Strategy of Tomato Sector in Mafraq, 2 (August).

Ishtiaque, A., Shrestha, M. and Chhetri, N. (2017). Rapid urban growth in Kathmandu valley, Nepal: monitoring land use land cover dynamics of himalayan city with landscape imageries. Environments, 4(4): 72, https://doi.org/10.3390/environments4040072

Kotler, P. and Armstrong, G. (1991). Principle of Marketing. London: Printice Hall Pvt. Ltd.

MoAD. (2015/16). Statistical Information on Nepalese Agriculture. Singha Durbar, Kathamandu: Monitoring, Evalation and Statistics Division, Agri-Statistics Section.

MoAD. (2011). Value chain analysis of off-season vegatables (OSV). Birendranagar, Surkhet, Nepal: High Value Agricultural Project in Hill and Mountain Areas 
(HVAP), Ministry of Agricultural Development, Government of Nepal.

Poudel, P. (2013). Marketing Margin Assessment of Off-Season Vegetables value chain in Surkhet Dailekh Road Corridor. Journal of Agriculture and Environment, 27-31.

Prasain, K. (2019). Tomato retail price hits the roof at Rs. 125 per kg in Kathmandu. Retrieved from The kathmandu Post: https://kathmandupost.com/ money/2019/05/20/tomato-retail-price-hits-the-roof-at-rs-125-per-kg-inKathmandu
Sharma, T. R. (2009). Analysis of Marketing of Tomato: A Case of Plastic house condition in Kaski, Nepal.

Timsina, K.P. and Shivakoti, G.P. (2018). Vegetables production and marketing: practic and perception of vegetable seed producers and fresh growers in Nepal. Agriculture and Food Security, 7: 11, https://doi.org/10.1186/s40066-018-0161-9

Vandernoot, J. and Hove, C.V. (2014). Disparities between development regions and district development committees in Nepal. International Advances in Economic Research, 20 (3): 353-354, https://doi.org/10.1007/s11294-014-9479-7 